\title{
Article
}

\section{Mangiferin: A Promising Anticancer Bioactive}

Khurana, Rajneet Kaur, Kaur, Ranjot, Lohan, Shikha, Singh, Kamalinder K and Singh, Bhupinder

Available at http://clok.uclan.ac.uk/14747/

Khurana, Rajneet Kaur, Kaur, Ranjot, Lohan, Shikha, Singh, Kamalinder K ORCID: 0000-0001-7325-0711 and Singh, Bhupinder (2016) Mangiferin: A Promising Anticancer Bioactive. Pharmaceutical Patent Analyst, 5 (3). pp. 169181. ISSN 2046-8954

It is advisable to refer to the publisher's version if you intend to cite from the work. http://dx.doi.org/10.4155/ppa-2016-0003

For more information about UCLan's research in this area go to http://www.uclan.ac.uk/researchgroups/ and search for <name of research Group>.

For information about Research generally at UCLan please go to http://www.uclan.ac.uk/research/

All outputs in CLoK are protected by Intellectual Property Rights law, including Copyright law. Copyright, IPR and Moral Rights for the works on this site are retained by the individual authors and/or other copyright owners. Terms and conditions for use of this material are defined in the policies page.

\section{CLoK}

Central Lancashire online Knowledge www.clok.uclan.ac.uk

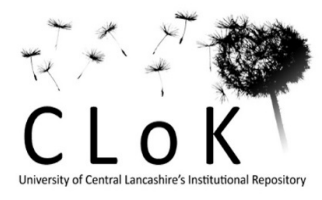




\section{Mangiferin: A Promising Anticancer Bioactive}

\section{Rajneet Kaur Khurana1, Ranjot Kaur', Shikha Lohan², Kamalinder K Singh' Bhupinder Singh ${ }^{1,2^{*}}$}

${ }^{1}$ University Institute of Pharmaceutical Sciences, UGC Centre of Advanced Studies, Panjab University, Chandigarh, 160 014, India

2UGC-Centre of Excellence in Applications of Nanomaterials, Nanoparticles and Nanocomposites (Biomedical Sciences), Panjab University, Chandigarh, 160 014, India

${ }^{3}$ School of Pharmacy and Biomedical Sciences, University of Central Lancashire, Preston, PR1 2HE, UK

*To whom correspondence should be addressed

Professor Bhupinder Singh Bhoop

$$
\text { M Pharm, Ph D, D St }
$$

Chairman, University Institute of Pharmaceutical Sciences

Coordinator, UGC Centre of Advanced Studies

Coordinator, UGC Center for Excellence in Nano Applications

Panjab University, Chandigarh 160 014, India

E-mail: bsbhoop@yahoo.com, bsbhoop@pu.ac.in

艪 +91 172 2534103, Fax: +91 1722543101 


\begin{abstract}
Of late, several biologically active antioxidants from natural products have been investigated by the researchers in order to combat the root cause of carcinogenesis, i.e., oxidative stress. Mangiferin, a therapeutically active C-glucosylated xanthone, is extracted from pulp, peel, seed, bark and leaf of Mangifera indica. These polyphenols of mangiferin exhibit antioxidant properties and tend to decrease the oxygen-free radicals, thereby reducing the DNA damage. Indeed, its capability to modulate several key inflammatory pathways undoubtedly helps in stalling the progression of carcinogenesis. The current review article emphasizes an updated account on the patents published on the chemopreventive action of Mangiferin, apoptosis induction made on various cancer cells, along with proposed antioxidative activities and patent mapping of other important therapeutic properties. Considering it as promising polyphenol, this paper would also summarize the diverse molecular targets of Mangiferin.
\end{abstract}

Keywords: Chemoprotective, Antioxidants, Anti-inflammatory, Apoptosis, Bioactive, Patent mapping, Multiple molecular targets, Extraction and isolation of polyphenols, Isomangiferin, Homomangiferin, 


\section{Introduction}

Cancer has been affecting mankind since decades. Repeated victims of this most devastating disease are vital organs like lung, liver, breast, colorectum, prostate, oesophagous and stomach. It has been spreading like havoc and is expected to take tens of millions newer patients into the fold by 2020 [1]. The key element significantly aggravating cancer is oxidative stress. Primarily, the inability of the body to detoxify the generated free radicals leads to cancer. A great deal of research has been undertaken across the global laboratories to combat this deadly disease. Even after enormous efforts and dedicated research conducted in this domain, the struggle to beat cancer still seems to be an ongoing process, if not a distant dream. Although various anticancer drugs, incorporated in various delivery systems are continuously being introduced in the market, yet each one is associated with the vital concerns of poor bioavailability, high cost, accompanied with off-target side effects [2]. Antioxidants, in this regard, have caught the clairvoyant eye of researchers for their chemopreventive usage against cancer. Many biologically active antioxidants extracted from diverse flora have been explored and identified by the academicians and industrial researchers. Fundamentally, these tend to scavenge the free radicals by interrupting the oxidative chain reactions [3].

One of the naturally occurring glycosylxanthone that has gained rapid importance recently, in this context is Mangiferin (Mgf). It is a polyphenolic Cglycoside, basically extracted from the leaves, stem barks and fruits of Mango tree, Mangifera indica from Anacardiaceae family. It is a heat-stable molecule with molecular weight less than 500 daltons. It has attracted the attention of the scientists worldwide, as it possesses numerous pharmacological activities other than acting merely as an antioxidant [4]. It is known to be an anti-inflammatory, anti-viral, analgesic, immunomodulatory [5] [6], antidiabetic [7] and many more. Several literature instances have cited and reported the ability of Mgf to inhibit 
the cancer cells by inducing apoptosis. It has been observed in various animal models that it could act as a potent antioxidant by reducing free radical species, thereby preventing the potential DNA damage [8]. Currently, Mgf is in advanced preclinical stages and its formulations are set to undergo clinical trials subsequently. The current review article will highlight the patents filed on Mgf emphasizing its role not only as an antioxidant, but also to uncover its other beneficial characteristics, propagating it as a promising futuristic bioactive.

\section{Source of Mangiferin: Extraction and Isolation}

Owing to its myriad pharmacological activities and easy availability, Mgf has allured the interest of the researchers to develop efficient extraction and isolation methods, which could result in its maximum yield. The prime source of Mgf is mango tree, which is found abundantly in nature [9]. Various ancient scriptures talk about the potential of this plant with high nutritive and medicinal values, associated with variegated families like Anacardiaceae [10], Podalyfrieae [11], Hypericoideae [12], etc (Figure 1).

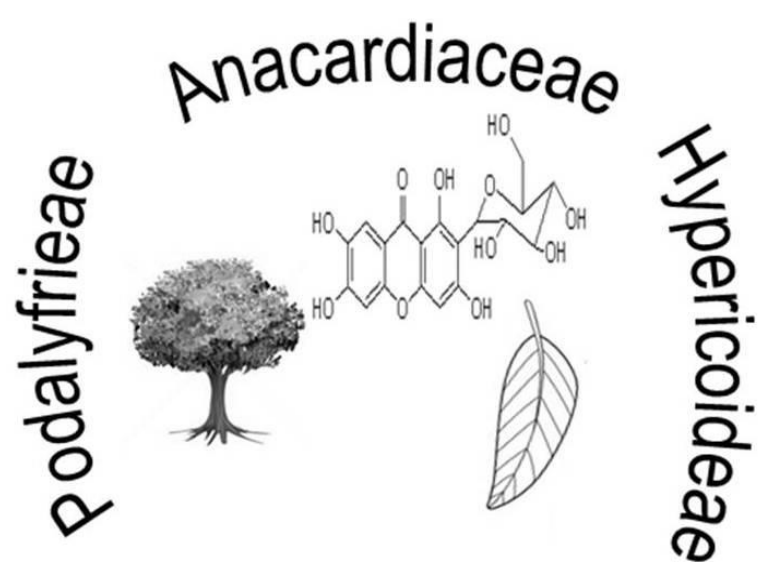

Figure 1: Existence of Mangiferin in three families.

Mgf can be extracted easily through decoctions and infusions of mango because of its hydrophilic nature. Various methods have been described in literature for the extraction and isolation of Mgf from diverse plant parts of mango. Some of the methods opted are Soxhlet extraction, microwave-assisted extraction, and subcritical 
extraction using solvents. However, the pitfalls associated with the use of these traditional techniques are the usage of high amount of solvents for extraction, more time consumption and economically less feasible [13]. To overcome these hiccups, various new techniques like supercritical fluid extraction (SFE) [14] and pressurized liquid extraction (PLE) [15], have been lately opted by researchers to obtain maximal yield in shorter time span. These techniques are preferred, as these processes are fast and environment friendly owing due to usage of green solvents such as carbon dioxide $\left(\mathrm{CO}_{2}\right)$, ethanol or water. Fernández-Ponce et al. (2012) reported subcritical water extraction method for the extraction of Mgf from varied plant varieties like Osteen, Kensington, Kent and Ataulfo. The extract showed highly potent in vitro antioxidant activity [13]. However, another scientific group, Kim et al., reported the extraction of Mgf from Mahkota Dewa employing same methodology, but making use of supercritical fluids [16]. Most commonly employed supercritical fluid is supercritical carbon dioxide $\left(\mathrm{scCO}_{2}\right)$, as it is documented to be ecologically safe, nontoxic and readily available [17]. The extraction yield from subcritical water method has been found to be quite close to the extraction yield using methanol as the extraction solvent, i.e., $21.7 \mathrm{mg} / \mathrm{g}$ [16]. Vrushali and Rathod (2014) described ultrasound three phase partitioning (UTPP) method for the extraction of Mgf from mango leaves. The method indicated the highest yield of $41 \mathrm{mg} / \mathrm{g}$ in 25 min vis-á-vis the conventional three-phase partitioning (TPP) that reported a yield of $28 \mathrm{mg} / \mathrm{g}$ in $2 \mathrm{~h}$. The latter offers a swift and economical technique for extraction of Mgf [18]. Further, Kulkarni and Rathod in 2015 reported the microwave assisted three phase partitioning extraction (MTPP) method. The results obtained indicated higher yield of Mgf by MTPP (95\%) in 5 mins as compared with the conventional technique like Soxhlet extraction which usually requires around $5 \mathrm{~h}$. As per the results obtained, the MTPP method proved to be more proficient and faster for extraction of Mgf [19]. In general, it is reported that the content of Mgf in various parts of Mango tree is approximately found to be $4.4 \mathrm{mg} / \mathrm{kg}$ in mango pulp [20], $42 \mathrm{mg} / \mathrm{kg}$ in seed kernel [21], $1690 \mathrm{mg} / \mathrm{kg}$ in mango peel [22] and most abundant $71.4 \mathrm{~g} / \mathrm{kg}$ in stem bark [23]. 
Therefore, the usage of newer techniques holds tremendous promise to provide maximal yield for wider exploration at lab and industrial scales.

\section{Structural elucidation and other isoforms}

To chemically synthesize Mgf being quite tedious as well as expensive, the best way to obtain it is considered to be via its extraction from various biological sources. Chemically, Mgf is C2-D-glucopyranosyl-1,3,6,7- tetrahydroxyxanthone as shown in Figure 2.

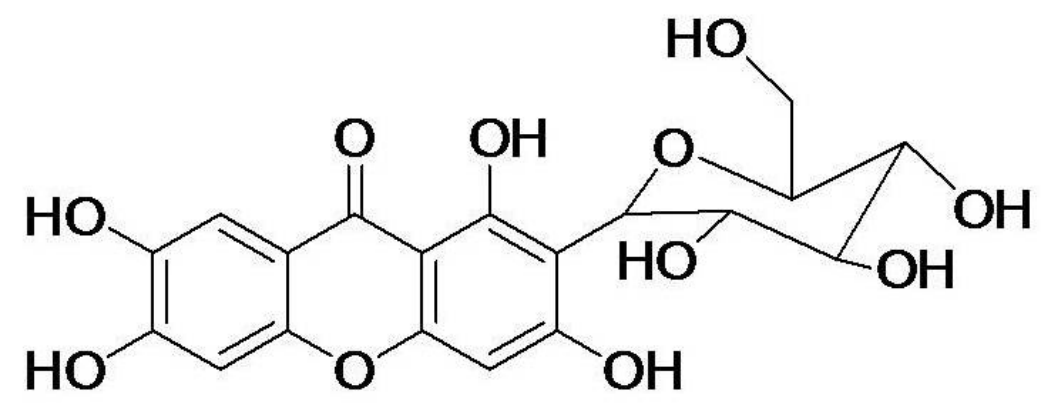

Figure 2. Structure of Mangiferin

In its chemical structure, C-glucosyl xanthone contains aromatic ring attached to the C-C bond of a glucose moiety, contributing towards its high polarity and water solubility. By and large, Mgf gratify Lipinski's rules, as for properties like molecular weight less than 500 with $\log$ P 2.73, fewer donor viz. acceptor groups, i.e., less than 5 and 10 to suffice hydrogen bonding; thus signifying the possible modifications that can be accomplished by the medicinal chemists to alter its physiochemical properties [24]. The presence of catechol ring, free hydroxyl groups, redox active aromatic system due to xanthone moiety, is responsible for the antioxidant activity of Mgf. In addition, it possesses proficient iron-chelating properties, resulting in the prevention of hydroxyl radicals to go in Fenton-type reactions principally responsible for oxidation [9].

The other isomeric forms like isomangiferin and homomangiferin are also present along with Mgf in the mango plant. The co-occurrence of these xanthones was reported earlier in 1975 by Saleh and El-Ansari. Isomangiferin, mostly present in 
Anemarrhena asphodeloides, chemically represented as 4- $\beta$-D-glucopyranosyl- 1, 3, 6, 7tetrahydroxy-9H-xanthen-9-one [25] whereas homomangiferin is 1,6,7-trihydroxy-3methoxy-2-C- $\beta$-D-glucopyranosyl-xanthone (Figure $3 \mathrm{a}, \mathrm{b}$ ).

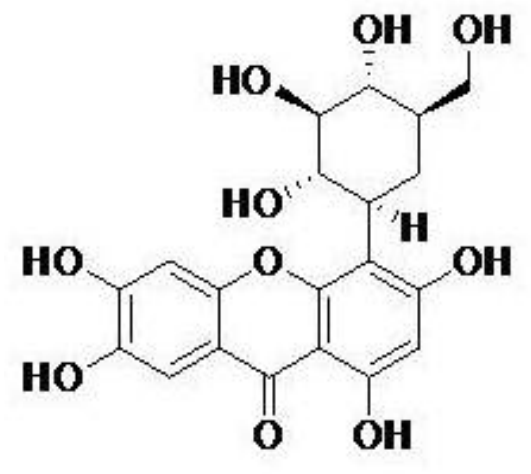

(a)<smiles>COc1cc2oc3cc(O)c(O)cc3c(=O)c2c(O)c1C1CC(CO)C(O)C(O)C1O</smiles>

(b)

Figure 3. Mangiferin isomeric forms a) Isomangiferin b) Homomangiferin

\section{Mechanism of action: As an antioxidant}

The antioxidant potential of this xanthone derivative has been well established over the years. As already stated, polyphenols contribute to its free radical scavenging properties by arresting the generated free radicals. The possible responsible mechanistic pathways for the same include, the formation of iron chelates, inhibiting lipooxygenases and scavenging free radicals [26].

Iron is an essential micronutrient that plays a key role in normal cellular physiology. Once the concentration of iron reaches the threshold level, it may result in the generation of catalytic response towards formation of oxyradicals. These free radicals have the ability to disrupt the cellular membrane lipids, nucleic acid chains, carbohydrates and proteins, ultimately impairing the normal cellular functions of body [27]. Mgf, in this regard may reduce the oxidative damage by forming iron chelates. It is well-documented that noranthyriol, a product of Mgf metabolism, exhibits strong iron-chelating property [26]. It was been found that Mgf preserves the integrity of mitochondrial membrane by protecting it from lipid peroxidation. 
Gilberto et al. (2007) reported that Mgf-Fe(III) complex protects the mitochondrial membrane thiols and glutathiones from oxidation [28]. Mgf, by scavenging these reactive species, maintains cellular integrity, thus minimizing the possible damage to erythrocytes [4].

\section{Targets for antioxidant properties of Mgf: Molecular level}

Since ages, polyphenols are known to modulate multiple molecular targets and signalling pathways. Mgf, serving as a potent polyphenol, has been shown to affect several biological processes, like inhibition of NF-kB and other transcription factors, reactive oxygen species (ROS), angiogenesis, and apoptosis including mitochondrial bioenergetics [29]. It is reported that the anticancer activity is achieved by cell cycle arrest and direct apoptosis, while its chemoprotective action could be attributed due to its antioxidant and anti-inflammatory activities [30]. These targets enable the chemopreventive actions of Mgf by inhibiting the initiation, promotion and metastasis of cancer. Figure 4 and Table 1 highlights the various targets aimed by Mgf to curb cancer. 


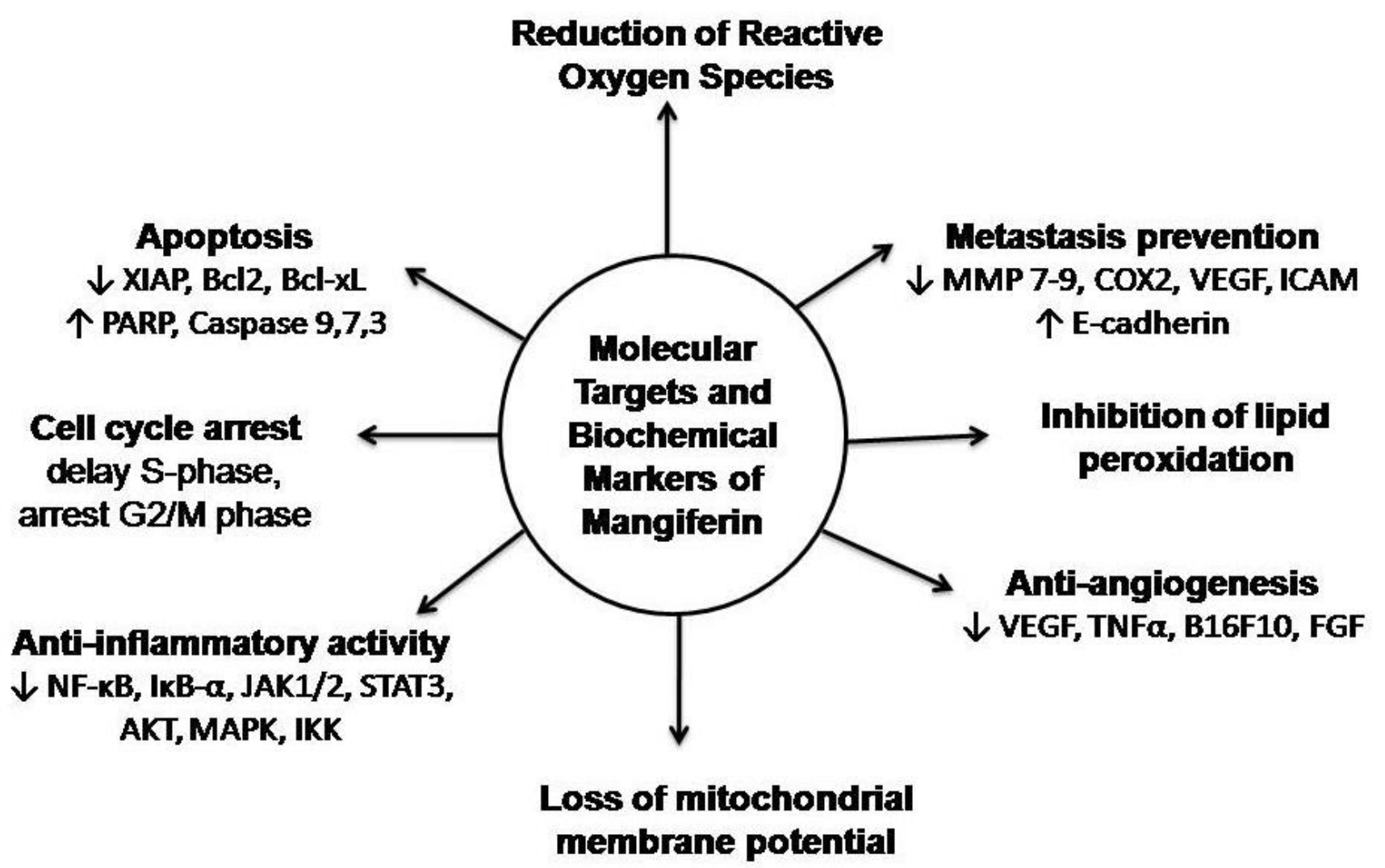

Figure 4. Diverse mechanisms for potential activity of Mangiferin

Table 1: Various molecular targets of Mgf to curb cancer

\begin{tabular}{|c|c|c|c|}
\hline Target & \multicolumn{2}{|c|}{ Biochemical markers } & References \\
\hline $\begin{array}{l}\text { Reactive oxygen species (ROS): } \\
\text { Mgf is known to scavenge ROS } \\
\text { generated in the cells. It is also } \\
\text { known to inhibit xanthine } \\
\text { oxidase, the enzyme responsible } \\
\text { for oxidation. }\end{array}$ & ROS & $\downarrow$ & [31-33] \\
\hline \multirow{6}{*}{$\begin{array}{l}\text { Anti-inflammatory: } \\
\text { Mgf is a potent inhibitor of } \\
\text { NFKB, IL-6, IL-8, CXCR4, XIAP, } \\
\text { TNF, ICAM1 and COX2. }\end{array}$} & NF-kB & $\downarrow$ & \multirow{6}{*}[34]{} \\
\hline & IкB- $\alpha$ & $\downarrow$ & \\
\hline & JAK1/2 & $\downarrow$ & \\
\hline & STAT3 & $\downarrow$ & \\
\hline & $\mathrm{AKT}$ & $\downarrow$ & \\
\hline & MAPK & $\downarrow$ & \\
\hline
\end{tabular}




\begin{tabular}{|c|c|c|c|}
\hline & IKK & $\downarrow$ & \\
\hline \multirow{4}{*}{$\begin{array}{l}\text { Anti-angiogenesis: } \\
\text { Mgf exhibits anti-angiogenic } \\
\text { activity by inhibiting the } \\
\text { growth of some tumors. }\end{array}$} & VEGF & $\downarrow$ & \multirow{4}{*}[35,36]{} \\
\hline & TNFa & $\downarrow$ & \\
\hline & B16F10 & $\downarrow$ & \\
\hline & FGF & $\downarrow$ & \\
\hline \multirow{5}{*}{$\begin{array}{l}\text { Apoptosis: } \\
\text { Mgf induces apoptosis by } \\
\text { suppressing NF-kB activation } \\
\text { and expressions of Bcl-xL and } \\
\text { XAIP. }\end{array}$} & $\begin{array}{c}\text { Caspase } \\
9,7,3\end{array}$ & $\uparrow$ & \multirow{5}{*}{ [37-41] } \\
\hline & XIAP & $\downarrow$ & \\
\hline & Bcl2 & $\downarrow$ & \\
\hline & Bcl-xL & $\downarrow$ & \\
\hline & PARP & $\uparrow$ & \\
\hline \multirow{5}{*}{$\begin{array}{l}\text { Metastasis: } \\
\text { Mgf inhibits the activation of } \beta \text { - } \\
\text { catenin pathway and thus acts } \\
\text { as an effective chemopreventive } \\
\text { agent against breast cancer. }\end{array}$} & MMP 7-9 & $\downarrow$ & \multirow{5}{*}{ [42] } \\
\hline & COX2 & $\downarrow$ & \\
\hline & VEGF & $\downarrow$ & \\
\hline & ICAM & $\downarrow$ & \\
\hline & E-cadherin & $\uparrow$ & \\
\hline \multicolumn{3}{|c|}{$\begin{array}{l}\text { Cell cycle arrest: } \\
\text { Mgf could delay S-phase, arrest } \mathrm{G}_{2} / \mathrm{M} \text { phase, leading to } \\
\text { apoptosis. Mgf triggers cell-cycle arrest via down-regulating } \\
\text { cdc2-cyclinB1 signalling pathway in breast cancer cells. }\end{array}$} & {$[40,43]$} \\
\hline \multicolumn{3}{|c|}{$\begin{array}{l}\text { Lipid peroxidation: } \\
\text { Polyphenols could inhibit the onset of lipid peroxidation and } \\
\text { evidently increase the serum antioxidant capacity, thus } \\
\text { accounting for its chemopreventive action. }\end{array}$} & [44] \\
\hline \multicolumn{3}{|c|}{$\begin{array}{l}\text { Mitochondrial membrane potential: } \\
\text { Mgf induces loss of mitochondrial membrane potential and } \\
\text { activates apoptotic proteins. }\end{array}$} & [45] \\
\hline
\end{tabular}

Apart from acting as antioxidant, Mgf possesses a repertoire of other useful properties. The specific patents in the light of each property have been obtained, and discussed underneath.

1. Cosmeceuticals: Gupta et al., 2004 invented a novel ion-pair delivery system in which a charge donor and a charge acceptor composition have been combined synergistically to enhance bioavailability, deposition, functional performance, and consumer aesthetics. This variegated composition was found to be safe and effective 
with antioxidants such as non-sulfhydryl donating groups which can enhance skin whitening efficacy [46].

Further, Gupta and Shyam (2006) explored efficacy of hydroxy acids esters as topical compositions serving as beneficial cosmetic and pharmaceutical agents [47]. Another invention by Peter and associates (2013) incorporates topically bioavailable antibacterial agent, Mgf, as antioxidant agent which could improve microcirculation. The combination cures acne, rosacea, controls excess sebum production and undesirable growth of bacteria or mites, as well as enhanced desquamation of follicular infundibulum cells [48].

Gupta and associates also disclosed an invention, with chirally correct polyene cyclodextrin acetals, and hemiacetals incorporated with antioxidants and antiinflammatory ketones, that were effective in providing skin clarification and disfigurements, treat acne, and lighten skin darkening resulting from cancer, diabetes, radiation treatments and chemotherapy [49].

2. Arthiritic disease: Park Dong-Suk et al., 2009 unravelled an invention comprising of the extract of Mgf mixed herbs with Lonicera japonica and Anemarrhena asphodeloides showing potent anti-inflammatory activity for safe and effective management of arthritis. The extract contained chlorogenic acid, besides Mgf as the standard component [50].

3. Breast cancer: Wang Ching-chiung in 2011 disclosed an ethyl acetate layer of methanolic extract of Aquilaria hulls for preventing cancer. The invention was tested on a group of cancer cell lines like colorectal, gastric, prostate, breast, pancreatic, lung, bladder, colon, cervical and hepatocellular carcinoma [51]. Truog and Buschmann (2014) invented a pharmaceutical composition comprising of phenylbutyric acid derivative, and a chemopreventive agent thereof for use in the prevention of cancer [52].

Also, Halbrook (2013) documented Mgf as a compound and in compositions which could inhibit DNA-dependent protein kinase (DNA-PK). The present DNA-PK inhibitors can be used as diagnostic and therapeutic methods useful in the field of cancer therapy. The reduced exposure to radiation and chemotherapy drugs 
improves a patient's prognosis with regard to unwanted adverse side effects that often accompany cancer treatments [53].

4. Colon and Lung cancer: Wang (2012), disclosed that an ethyl acetate layer of methanol extract of Aquilaria hulls effectively kills the cancerous cells. The extracts of the same has significant amount of cucurbitacins, which are effective in treating/preventing cancers [51]. Another research conducted by Siegelin and Altieri (2011) revealed a method of enhancing apoptosis in one or more mammalian cells, with at least one mitochondrial-targeted chaperone inhibitor and at least one agent selected from the group consisting of a death receptor agonist, an autophagy inhibitor, and a NF-kB signalling pathway inhibitor, i.e., $\mathrm{Mgf}$ [54].

Further, Gerk in 2013, proposed a method for enhancing the bioavailability of orally bioactive phenolic compounds incorporated with one or more inhibitors like presystemic metabolism sulfotransferase (SULTs). Another clinical utilities of Mgf include diabetes, hyperlipidemia, cholestasis, obesity, metabolic syndrome, various cancers, inflammatory diseases, arthritis and anti-aging activities [55]. Meanwhile, surmounthing the above inventions, Huang and $\mathrm{Wu}$ in 2014 discovered a novel method for treating gastrointestinal spasm in a subject having Crohn's disease or ulcerative colitis. The method comprised of administering an effective amount of water soluble polyphenols consisting of tannins [56].

5. Leukemia: Khwaja and Friedman (1999) invented a delivery system comprising of St. John's Wort materials and unearthing methods for preparing medicinally useful and pharmaceutically acceptable forms which could determine the degree of the given biological activity for each of the marker fractions to provide a bioactivity fingerprint of the representative aliquot [57].

6. Multiple myeloma: Leonard (2011) disclosed a method for treating autoimmune conditions by administering a formulation comprising of mammalian IL-12 antagonist administered during autoimmune conditions, where there is an increase in the levels of IFN- $\gamma$ or TNF- $\alpha$. The said formulation has been prescribed particularly during multiple sclerosis, systemic lupus erythematosus, rheumatoid arthritis, autoimmune pulmonary inflammation, Guillain-Barre syndrome, 
autoimmune thyroiditis, insulin dependent diabetes melitis and autoimmune inflammatory eye disease [58].

7. Hepatocellular: Omoigui (2006) invented novel compositions and methods containing Mgf for preventing and treating disorders like atherosclerosis, peripheral vascular disease, coronary artery disease, osteoporosis, type 2 diabetes, dementia and various forms of arthritis. Therapeutically effective dosage forms reported in literature for cancer primarily consist of $\mathrm{Mgf}$ in combination with statins, bisphosphonates, cholesterol lowering agents or techniques, interleukin-6 inhibitor, oligonucleotides, tyrosine kinases inhibitors and nuclear factor- $\mathrm{kB}$ (NF-kB) inhibitors etc [59].

8. Skin cancer: Huang and Wu (2014) investigated some polyphenols as antioxidants to scavenge unwanted reactive oxygen species which can affect cell-to-cell signalling, receptor sensitivity, inflammatory enzyme activity and even gene regulation in animals [60, 61]. Further, Gupta (2009), reported salient features of water insoluble polycyclic polyisoprenoids conjugated with sugar esters, wherein the alcohol part, and the sugar lactone moiety of said sugar esters are useful for treating multiple skin conditions and ailments [62].

9. Ovarian and Prostate cancer: Dasse (2008) reported that Mgf and various other antioxidants could inhibit the fatty acid amide hydrolase (FAAH) activity which could otherwise lead to increased levels of fatty acid amides to very well manage the ovarian cancer [63]. Supporting the same, Huang (2014) also provided methods incorporating these antioxidants that could treat and provide relief from prostate cancer pain [64].

Table 2 highlights various patents published, promoting the other fascinating properties of Mgf. 
Table 2: Patents emphasizing the captivating properties of Mangiferin

\begin{tabular}{|c|c|c|c|c|c|c|}
\hline $\begin{array}{l}\text { S. } \\
\text { No. }\end{array}$ & Title & $\begin{array}{c}\text { Application } \\
\text { number }\end{array}$ & $\begin{array}{c}\text { Publication } \\
\text { date }\end{array}$ & Inventors & Details & Reference \\
\hline 1. & Analgesic & $\begin{array}{l}\text { KR2014/00125 } \\
2\end{array}$ & $10 / 30 / 2014$ & $\begin{array}{l}\text { Kim Dong Hyun; } \\
\text { Han Myung Joo }\end{array}$ & $\begin{array}{l}\text { Neomangiferin, extracted from } \\
\text { Rhizoma coptidis, can excellently } \\
\text { prevent as well as treat colitis in } \\
\text { animal models. Also it could be } \\
\text { used be used as an ingredient for } \\
\text { food and pharmaceuticals. }\end{array}$ & [65] \\
\hline 2. & Anthelminthic & $\begin{array}{l}\text { EP2009/05434 } \\
9\end{array}$ & $10 / 15 / 2009$ & $\begin{array}{l}\text { Talamond } \\
\text { Pascale Chênes; } \\
\text { Verts Eyragues; } \\
\text { Mondolot } \\
\text { Laurence } \\
\text { Mourèze; } \\
\text { Gargadennec } \\
\text { Annick; } \\
\text { De Kochko } \\
\text { Alexandre; } \\
\text { Hamon Serge; } \\
\text { Fruchier Alain } \\
\text { Fontaine; } \\
\text { Montarnaud } \\
\text { Campa Claudine }\end{array}$ & $\begin{array}{l}\text { Glycosyl xanthone derivatives, } \\
\text { particularly Mgf and } \\
\text { isomangiferin extracted from } \\
\text { plants of the Rubiaceae family, } \\
\text { especially of the Coffea genus has } \\
\text { proven medicinal properties. }\end{array}$ & {$[66]$} \\
\hline 3. & Antiallergic & JP2009/066203 & $04 / 01 / 2010$ & $\begin{array}{l}\text { Fujifilm } \\
\text { Corporation }\end{array}$ & $\begin{array}{l}\text { Pulverized product has been } \\
\text { extracted from the genus Salacia } \\
\text { and has proved to be an }\end{array}$ & [67] \\
\hline
\end{tabular}




\begin{tabular}{|c|c|c|c|c|c|c|}
\hline & & & & $\begin{array}{l}\text { UEDA, Fumitaka; } \\
\text { Kakinuma } \\
\text { Chihaya, } \\
\text { Serizawa, Yuriko }\end{array}$ & $\begin{array}{l}\text { immunopotentiator } \\
\text { antiallergic agent. }\end{array}$ & \\
\hline 4. & Antiamoebic & $09 / 728051$ & $09 / 02 / 2003$ & $\begin{array}{l}\text { Winter Rolf W; } \\
\text { Riscoe Michael } \\
\text { K; Hinrichs, } \\
\text { David J. }\end{array}$ & $\begin{array}{l}\text { Xanthone derivatives, such as 3,5- } \\
\text { bis-ع-(N,N-diethylamino) } \\
\text { amyloxyxanthone, acts on } \\
\text { Plasmodium falciparum and } \\
\text { Leishmania Mexicana. These } \\
\text { compositions are additionally } \\
\text { useful for forming soluble } \\
\text { complexes with heme and } \\
\text { porphyrins. }\end{array}$ & [68] \\
\hline 5. & $\begin{array}{l}\text { Anti- } \\
\text { artherosclerosis }\end{array}$ & $14 / 547537$ & $05 / 21 / 2015$ & $\begin{array}{l}\text { Deshpande } \\
\text { Jayant; } \\
\text { Ghanam Khadija; } \\
\text { Ewart Stephen; } \\
\text { Juturu Vijaya }\end{array}$ & $\begin{array}{l}\text { A Salacia composition activates } \\
\text { hormone sensitive lipase, and } \\
\text { manages a healthy lipid profile } \\
\text { through inhibition of HMG-CoA } \\
\text { reductase enzyme. }\end{array}$ & [69] \\
\hline 6. & Antibacterial & $13 / 440446$ & $07 / 26 / 2012$ & Gupta Shyam K. & $\begin{array}{l}\text { The present invention discloses } \\
\text { certain derivatives of artemisinin } \\
\text { and the active principles } \\
\text { contained in Artemisia } \\
\text { annua extracts with amino acids, } \\
\text { peptides, amino sugars, and the } \\
\text { salts thereof. The compounds of } \\
\text { the present invention possess } \\
\text { wide-spectrum antibacterial and } \\
\text { antifungal activities. }\end{array}$ & [70] \\
\hline
\end{tabular}




\begin{tabular}{|c|c|c|c|c|c|c|}
\hline 7. & Antidiabetic & $13 / 063804$ & $04 / 24 / 2012$ & $\begin{array}{l}\text { Krishnan Geetha } \\
\text { G. }\end{array}$ & $\begin{array}{l}\text { An herbal formulation for } \\
\text { prevention and treatment of } \\
\text { diabetes and associated } \\
\text { complications, comprising of } \\
\text { extracts from selected Indian } \\
\text { medicinal herbs. }\end{array}$ & [71] \\
\hline 8. & Antifungal & $12 / 116040$ & $08 / 28 / 2008$ & $\begin{array}{l}\text { Krishnan } \\
\text { Venkataram }\end{array}$ & $\begin{array}{l}\text { This invention relates to the field } \\
\text { of polymeric materials that can be } \\
\text { used in combination with a wide } \\
\text { variety of antioxidants. }\end{array}$ & [72] \\
\hline 9. & Anti-hypertensive & $14 / 084793$ & $03 / 27 / 2014$ & $\begin{array}{lr}\text { Auriol } & \text { Daniel; } \\
\text { Nalin } & \text { Renaud; } \\
\text { Robe } & \text { Patrick } \\
\text { Lefevre } & \text { Fabrice }\end{array}$ & $\begin{array}{l}\text { The invention relates to the } \\
\text { preparation of phenolic } \\
\text { derivatives by enzymatic } \\
\text { condensation of phenolics } \\
\text { selected among pyrocatechol or } \\
\text { its derivatives with the glucose } \\
\text { moiety of sucrose as } \\
\text { antihypertensive } \\
\text { cardioprotective agent }\end{array}$ & [73] \\
\hline 10. & $\begin{array}{l}\text { Anti- } \\
\text { inflammatory }\end{array}$ & $\begin{array}{l}\text { JP20070001878 } \\
37\end{array}$ & $02 / 05 / 2009$ & $\begin{array}{l}\text { Matsuda } \\
\text { Hideaki; } \\
\text { Nishida Shozo }\end{array}$ & $\begin{array}{l}\text { The antiphlogistic agent as the } \\
\text { remedy of the inflammatory } \\
\text { diseases like arthritis comprise of } \\
\text { Mgf as an active ingredient. }\end{array}$ & [74] \\
\hline 11. & Antimicrobial & $12 / 116006$ & $09 / 25 / 2008$ & $\begin{array}{l}\text { Krishnan } \\
\text { Venkataram }\end{array}$ & $\begin{array}{l}\text { This invention relates to the field } \\
\text { of polymeric materials that can be } \\
\text { used in combination with a wide } \\
\text { variety of substrates, to act as } \\
\text { antimicrobial, antibacterial, and }\end{array}$ & [75] \\
\hline
\end{tabular}




\begin{tabular}{|c|c|c|c|c|c|c|}
\hline & & & & & antifungal agents. & \\
\hline 12. & Antioxidant & $13 / 084709$ & $07 / 03 / 2012$ & $\begin{array}{l}\text { Gupta Shyam K; } \\
\text { Walker Linda }\end{array}$ & $\begin{array}{l}\text { This invention relates to certain } \\
\text { amides of amino acids, peptides, } \\
\text { and amino sugars along with } \\
\text { anti-inflammatory, agents like } \\
\text { Mgf, inhibiting the concomitant } \\
\text { onset intra-cellular } \\
\text { inflammation including } \\
\text { activation/inactivation of matrix } \\
\text { metalloproteases (MMP), } \\
\text { tyrosinase, proteasomes, and } \\
\text { other enzymes in mammals. }\end{array}$ & [76] \\
\hline 13. & Antiproliferative & $13 / 023594$ & $06 / 30 / 2011$ & $\begin{array}{l}\text { Hoffmann Erika; } \\
\text { Horres Roland; } \\
\text { Faust Volker; } \\
\text { Schreiber } \\
\text { Helmut; } \\
\text { Von Holst Armin; } \\
\text { Hoffmann } \\
\text { Michael }\end{array}$ & $\begin{array}{l}\text { The present invention is directed } \\
\text { to a method for coating catheter } \\
\text { balloons with a defined amount } \\
\text { of a pharmacologically active } \\
\text { agent like Mgf as an } \\
\text { antiproliferative agent. }\end{array}$ & [77] \\
\hline 14. & Antiviral & $\begin{array}{l}\text { PCT/US2005/ } \\
047105\end{array}$ & $07 / 27 / 2006$ & Ghosal Shibnath & $\begin{array}{l}\text { The present invention relates to } \\
\text { pharmaceutical or nutritional } \\
\text { compositions of polyherbal } \\
\text { extracts useful as anti-viral or } \\
\text { immune-supporting agents ideal } \\
\text { during the maintenance phase of } \\
\text { the treatment, following an initial } \\
\text { viral load reduction phase in }\end{array}$ & [78] \\
\hline
\end{tabular}




\begin{tabular}{|c|c|c|c|c|c|c|}
\hline & & & & & $\begin{array}{l}\text { which it is used as an adjuvant to } \\
\text { conventional anti-viral drug } \\
\text { therapy. }\end{array}$ & \\
\hline 15. & Arthritic & $12 / 865995$ & $01 / 06 / 2011$ & $\begin{array}{l}\text { Park Dong-suk; } \\
\text { Yoo Myung; } \\
\text { Chul; Choi Do- } \\
\text { young; Yang } \\
\text { Hyung; Baek } \\
\text { Yong-hyeon; } \\
\text { Huh Jeong-eun; } \\
\text { Kim Kyoung Soo; } \\
\text { Cho Yong-baik; } \\
\text { Jung In Ho; } \\
\text { Hur Jong Hyun; } \\
\text { Lee Jae Dong }\end{array}$ & $\begin{array}{l}\text { The saponins, Mgf and } \\
\text { isomangiferin, help in inhibition } \\
\text { or prevention of arthritic } \\
\text { diseases. }\end{array}$ & {$[79]$} \\
\hline 16. & Cardioprotective & $13 / 063804$ & $09 / 29 / 2011$ & $\begin{array}{l}\text { Krishnan Geetha } \\
\text { G }\end{array}$ & $\begin{array}{l}\text { Many of the existing antidiabetic } \\
\text { drugs lead to drug resistance in } \\
\text { patients, where and the isoforms } \\
\text { of Mgf have proved to be quite } \\
\text { efficacious. }\end{array}$ & {$[80]$} \\
\hline 17. & Gastroprotective & $13 / 772264$ & $05 / 06 / 2014$ & $\begin{array}{l}\text { Huang Alexander } \\
\text { L; Wu Gin }\end{array}$ & $\begin{array}{l}\text { Antioxidant and } \\
\text { inflammatory activities of } \mathrm{Mgf} \\
\text { are quite useful for treating } \\
\text { gastrointestinal spasm. }\end{array}$ & [81] \\
\hline 18. & $\begin{array}{l}\text { Immunomodulato } \\
\text { ry }\end{array}$ & $\begin{array}{l}\text { AU2013/00030 } \\
3\end{array}$ & $09 / 26 / 2013$ & Thomas Ranjeny & $\begin{array}{l}\text { For treating or preventing joint } \\
\text { damage, Mgf could elicit an } \\
\begin{array}{l}\text { antigen-specific } \\
\text { response. }\end{array}\end{array}$ & {$[82]$} \\
\hline
\end{tabular}




\begin{tabular}{|c|c|c|c|c|c|c|}
\hline 19. & Lipolytic & IB2014/002990 & $05 / 28 / 2015$ & $\begin{array}{l}\text { Deshpande } \\
\text { Jayant; Khadija; } \\
\text { Stephen; } \\
\text { Juturu Vijaya }\end{array}$ & $\begin{array}{l}\text { Polyphenols, extracted from } \\
\text { Salacia composition described } \\
\text { herein, significantly reduce } \\
\text { appetite, activate hormone- } \\
\text { sensitive lipase, and manage a } \\
\text { healthy lipid profile through } \\
\text { inhibition of HMG-CoA } \\
\text { reductase enzyme, responsible } \\
\text { for cholesterol metabolism. }\end{array}$ & [83] \\
\hline 20. & Neuroprotective & $12 / 159781$ & $05 / 21 / 2009$ & $\begin{array}{lr}\text { Matute } & \text { Almau; } \\
\text { Carlos } & \\
\text { Gomez; } & \text { Maria } \\
\text { Victoria } & \text { Sanchez; } \\
\text { Esparza } & \text { Rosario } \\
\text { Campos; } & \text { Alfonso } \\
\text { Elena } & \text { Alberdi; } \\
\text { Gottlieb } & \\
\text { Miroslav; } & \\
\text { Bilbao } & \text { Gaskon } \\
\text { Ibarretxe; } & \text { Garcia } \\
\text { Jose } & \text { Maria } \\
\text { Delgado; } & \\
\text { Gruart } & \text { Masso } \\
\text { Agnes } & \text { I; } \\
\text { Leal Campanario, } \\
\text { Rocio }\end{array}$ & $\begin{array}{l}\text { The invention relates to the use of } \\
\text { morin and Mgf for the treatment } \\
\text { of a neurodegenerative disease } \\
\text { and symptoms associated with } \\
\text { ageing. }\end{array}$ & [84] \\
\hline 21. & $\begin{array}{l}\text { Prevent } \\
\text { osteoporosis }\end{array}$ & $\begin{array}{l}\text { PCT/GB2004/ } \\
001695\end{array}$ & $11 / 04 / 2004$ & $\begin{array}{l}\text { Chambers } \\
\text { Timothy John; } \\
\text { Fuller Karen; }\end{array}$ & $\begin{array}{l}\text { Bone loss disorders can be treated } \\
\text { or prevented by administration of } \\
\text { an agent which increases the }\end{array}$ & [85] \\
\hline
\end{tabular}




\begin{tabular}{|c|c|c|c|c|c|c|}
\hline & & & & $\begin{array}{l}\text { Jagger } \\
\text { Christopher } \\
\text { John; Lean Jenny } \\
\text { Maree }\end{array}$ & levels of oxidant defences. & \\
\hline 22. & Radioprotective & $\begin{array}{l}\text { PCT/US1997/ } \\
006988\end{array}$ & 10/23/1997 & $\begin{array}{l}\text { Khwaja } \text { Tasneem } \\
\text { A; Friedman } \\
\text { Elliot P }\end{array}$ & $\begin{array}{l}\text { The botanical extracts are not } \\
\text { only medicinally and } \\
\text { pharmaceutically acceptable but } \\
\text { also enable the subsequent } \\
\text { fingerprints in the processing of } \\
\text { botanical materials to produce } \\
\text { drugs which could be } \\
\text { radioprotective. }\end{array}$ & [86] \\
\hline
\end{tabular}




\section{Conclusion and Future Prospects:}

Albeit the literature available so far on Mgf is scanty, yet every single piece of information filed, confirms its significant effect on fundamental biological events and processes like stimulating mitochondrial respiration, while suppressing oxidative stress and inflammation. In the light of the above, the current review has attempted to summarize reported patents on chemopreventive and curative potential of Mgf. Its pivotal role to suppress multiple molecular targets in both chronic inflammation and cancer has also been highlighted. Apart from that, it holds great potential to be developed into a nutritional and/or pharmacological therapeutics, as it stimulates mitochondrial respiration, glycolysis and lipolysis. In simple words, we could state that it suppresses gluconeogenesis and lipogenesis. These prominent pharmacological actions have been corroborated by numerous patents documented till date. Also, it is capable of eliciting broad spectrum beneficial biological effects, like analgesic, antipyretic, immunomodulator, antiviral, anthelmintic, antiallergic, antihistaminic, cardioprotective and antiamoebic, by modulating multiple targets [87].

The futuristic research should be focussed on extensive mechanistic investigations into various other unexplored bioactivities, its complete pharmacokinetic exploration to establish ADME patterns, as well as on eagerly awaited pre-clinical and clinical evaluation of pure Mgf, its homologues and isomers, complex extracts or fractions from plants rich in xanthone C-glucosides. An important aspect of research that still needs to be undertaken is to elucidate the issues related to biosynthesis of Mgf and other hydroxyxanthones in plant cells, describing their physiological and endogenous role in plants and the change in content with environmental factors [88]. Detailed investigations and clinical trials, nevertheless, are needed to completely understand its exact mechanism of action against different malignancies and to fully exploit its potential therapeutic effects [89]. As it has low potency and bioavailability, it certainly needs extensive exploration in terms of structure-activity relationship studies. Cheminformatic tools can be used to carry out further studies 
establishing the ostensible relationship of structure and activity amongst Mgf and its derivatives. Experimental evidence as well as predictive computational studies, done so far raise a possibility that Mgf could be developed into a multi-target drug. Considering the pertinent information gathered through such patents, Mgf certainly proves to be a promising candidate for futuristic research and development as a part of the multi-potent drug delivery systems. Hence, it seems to be a promising molecule holding ample scope for researchers to work further in its aspects, to unexplored so far.

\section{Conflicts of interest:}

The authors declare no conflict interest.

\section{Acknowledgement:}

Rajneet Kaur Khurana, Ranjot Kaur and Shikha Lohan acknowledge the University Grant Commission (UGC), New Delhi, India for financial grants to them.

\section{References:}

1. Bray F, Moller B. Predicting the future burden of cancer. Nat. Rev. Cancer. 6(1), 63-74. (2006).

2. Nersesyan H, Slavin KV. Current aproach to cancer pain management: Availability and implications of different treatment options. Ther. Clin. Risk Manag. 3(3), 381-400 (2007).

3. Jayaprakash V, Marshall JR. Selenium and other antioxidants for chemoprevention of gastrointestinal cancers. Best Pract Res Clin. Gastroenterol. 25(4-5), 507-518 (2011).

4. Rodriguez J, Di Pierro D, Gioia M et al. Effects of a natural extract from Mangifera indica $\mathrm{L}$, and its active compound, mangiferin, on energy state and lipid peroxidation of red blood cells. Biochim. Biophys. Acta. 1760(9), 1333-1342 (2006).

5. Leiro J, Arranz JA, Yanez M, Ubeira FM, Sanmartin ML, Orallo F. Expression profiles of genes involved in the mouse nuclear factor-kappa B signal transduction pathway are modulated by mangiferin. Int. Immunopharmacol. 4(6), 763-778. (2004). ${ }^{* *}$ (Elucidate anticancer mechanism of mangiferin ).

6. Sarkar A, Sreenivasan Y, Ramesh GT, Manna SK. Beta-D-Glucoside suppresses tumor necrosis factor-induced activation of nuclear transcription factor kappaB but potentiates apoptosis. J. Biol. Chem. 279(32), 33768-33781 (2004). 
7. Ojewole JA. Antiinflammatory, analgesic and hypoglycemic effects of Mangifera indica Linn. (Anacardiaceae) stem-bark aqueous extract. Methods Find. Exp. Clin. Pharmacol. 27(8), 547-554 (2005). ** (Elucidate other activities of mangiferin ).

8. Zhang BF, Jun; Chen, Yan. Antioxidant Effect of Mangiferin and its Potential to be a Cancer Chemoprevention Agent. Lett. Drug Des. Discov. 10, 239-244 (2013). ${ }^{* *}$ (Elucidate other activities of mangiferin with their mechanisms).

9. Matkowski A, Kus P, Goralska E, Wozniak D. Mangiferin - a bioactive xanthonoid, not only from mango and not just antioxidant. Mini Rev. Med. Chem. 13(3), 439-455 (2013). * (Elaborate basics of mangiferin).

10. Sanchez GM, Re L, Giuliani A, Núñez-Sellés AJ, Davison GP, León-Fernández OS. Protective effects of Mangifera indica L. extract, mangiferin and selected antioxidants against TPA-induced biomolecules oxidation and peritoneal macrophage activation in mice. Pharmacol. Res. 42(6), 565-573 ( 2000).

11. De Nysschen A. M., Van Wyk B.E., Van Heerden F. R., A.L. S. The major phenolic compounds in the leaves of Cyclopia species (honeybush tea). Biochem. Syst. Ecol. 24(3), 243-246 (1996).

12. Kitanov GM, Nedialkov PT. Mangiferin and isomangiferin in some Hypericum species. Biochem. Syst. Eco. 26(6), 647-653 (1998). ** (Elaborate other isoforms of mangiferin).

13. Fernández-Ponce MT, Casas L, Mantell C, RodrÃguez M, MartÃnez de la Ossa E. Extraction of antioxidant compounds from different varieties of Mangifera indica leaves using green technologies. J. Supercrit. Fluids. 72, 168175 (2012).

14. Kulkarni VM, Rathod VK. Extraction of mangiferin from Mangifera indica leaves using three phase partitioning coupled with ultrasound. Ind. Crop. Prod. 52, 292-297 (2014).

15. Benthin B, Danz H, Hamburger M. Pressurized liquid extraction of medicinal plants. J. Chromatogr. A. 837(1-2), 211-219 (1999).

16. Kim W-J, Veriansyah B, Lee Y-W, Kim J, Kim J-D. Extraction of mangiferin from Mahkota Dewa (Phaleria macrocarpa) using subcritical water. J. Ind. Eng. Chem. 16(3), 425-430 (2010).

17. Reverchon E, De Marco I. Supercritical fluid extraction and fractionation of natural matter. J. Supercrit. Fluids. 38(2), 146-166 (2006).

18. Vrushali M. Kulkarni, Rathod VK. Extraction of mangiferin from Mangifera indica leaves using three phase partitioning coupled with ultrasound. Ind. Crop Prod. 52, 292- 297 (2014).

19. Kulkarni VM, Rathod VK. A novel method to augment extraction of mangiferin by application of microwave on three phase partitioning. Biotechnol. Rep. 6, 8-12 (2015).

20. Schieber A, Ullrich W, Carle R. Characterization of polyphenols in mango puree concentrate by HPLC with diode array and mass spectrometric detection. Innov. Food Sci. Emerg. Tech. 1(2), 161-166 (2000). 
21. Abdalla AEM, Darwish SM, Ayad EHE, El-Hamahmy RM. Egyptian mango by-product 1. Compositional quality of mango seed kernel. Food. Chem. 103(4), 1134-1140 (2007).

22. Berardini N, Knodler M, Schieber A, Carle R. Utilization of mango peels as a source of pectin and polyphenolics. Innov. Food Sci. Emerg. Tech. 6(4), 442-452 (2005).

23. Nunez Selles AJ, Velez Castro HT, Aguero-Aguero J et al. Isolation and quantitative analysis of phenolic antioxidants, free sugars, and polyols from mango (Mangifera indica L.) stem bark aqueous decoction used in Cuba as a nutritional supplement. J. Agric. Food Chem. 50(4), 762-766 (2002).

24. Raihan H. Mirza, Nan Chi, Chi Y. Therapeutic Potential of the Natural Product Mangiferin in Metabolic Syndrome. J. Nutr. Ther. 2, $74-79$ (2013). * (Explain role of mangiferin in curbing diseases).

25. Saleh NA, El-Ansari MA. Polyphenolics of twenty local varieties of Mangifera indica. Planta. Med. 28(2), 124-130 (1975).

26. Andreu GP, Delgado R, Velho JA, Curti C, Vercesi AE. Iron complexing activity of mangiferin, a naturally occurring glucosylxanthone, inhibits mitochondrial lipid peroxidation induced by Fe2+-citrate. Eur. J. Pharmacol. 513(1-2), 47-55 (2005).

27. Britton RS, Leicester KL, Bacon BR. Iron toxicity and chelation therapy. Int. J. Hematol. 76(3), 219-228. (2002).

28. Gilberto L. Pardo-Andreu, Renata A. Cavalheiro, Daniel J. Dorta et al. Fe(III) Shifts the Mitochondria Permeability Transition-Eliciting Capacity of Mangiferin to Protection of Organelle. J. Pharmacol. Exp. Ther. 320(2), 646-653 (2007).

29. Benard O, Chi Y. Medicinal properties of mangiferin, structural features, derivative synthesis, pharmacokinetics and biological activities. Mini Rev. Med. Chem. 15(7), 582-594 (2015). *(Holistic overview of mangiferin).

30. Rajendran P, Rengarajan T, Nandakumar N, Divya H, Nishigaki I. Mangiferin in cancer chemoprevention and treatment: pharmacokinetics and molecular targets. J. Recept. Signal. Transduct. Res. 35(1), 76-84 (2015). * (Mechanistic understanding of mangiferin targeting on tumor cells).

31. Agarwala S, Rao B, Mudholkar K, Bhuwania R, Rao S. Mangiferin, a dietary xanthone protects against mercury-induced toxicity in HepG2 cells. Environ. Toxicol. 27(2), 117-127, (2012).

32. Stoilova I, Jirovetz L, Stoyanova A, Krastanov A, Gargova S, Ho L. Antioxidant activity of the polyphenol mangiferin. EJEAFChe. 713, 2706-2716 (2008).

33. Assim A, Alfadda, Sallam RM. Reactive Oxygen Species in Health and Disease. J. Biomed. Biotechnol. ID 936486, 1-14 (2012).

34. Garcia-Rivera D, Delgado R, Bougarne N, Haegeman G, Berghe WV. Gallic acid indanone and mangiferin xanthone are strong determinants of immunosuppressive anti-tumour effects of Mangifera indica L. bark in MDAMB231 breast cancer cells. Cancer Lett. 305(1), 21-31 (2011). 
35. Delgado-Hernandez R, Magariño Y, Hernandez-Balmaseda et al. Antiangiogenic effects of Mangifera indica 1. stem bark extract and its natural glucoxilxanthone, mangiferin. http:/ / www.pa2online.org/abstracts/ vol10issue3abst089p.pdf. (Accessed on 06 January 2016).

36. Daud NH, Aung CS, Hewavitharana et al. Mango extracts and the mango component mangiferin promote endothelial cell migration. J. Agri. Food Chem. 58(8), 5181-5186. (2010).

37. Pan LL, Wang AY, Huang YQ, Luo Y, Ling M. Mangiferin induces apoptosis by regulating Bcl-2 and Bax expression in the CNE2 nasopharyngeal carcinoma cell line. Asian Pac. J. Cancer Prev. 15(17), 7065-7068 ( 2014).

38. Bartoszewski R, Hering A, Marszall M et al. Mangiferin has an additive effect on the apoptotic properties of hesperidin in Cyclopia sp. tea extracts. PLoS One. 9(3), e92128 (2014).

39. Shoji K, Tsubaki M, Yamazoe Y et al. Mangiferin induces apoptosis by suppressing Bcl-xL and XIAP expressions and nuclear entry of NF-kappaB in HL-60 cells. Arch. Pharm. Res. 34(3), 469-475 (2011).

40. du Plessis-Stoman D, du Preez J, van de Venter M. Combination treatment with oxaliplatin and mangiferin causes increased apoptosis and downregulation of NFkappaB in cancer cell lines. Afr. J. Tradit. Complement Altern. Med. 8(2), 177-184 (2011).

41. Padma VV, Kalaiselvi P, Yuvaraj R, Rabeeth M. Mangiferin induces cell death against rhabdomyosarcoma through sustained oxidative stress. Integr. Med. Res. 4(2), 66-75 (2015).

42. Li H, Huang J, Yang B et al. Mangiferin exerts antitumor activity in breast cancer cells by regulating matrix metalloproteinases, epithelial to mesenchymal transition, and beta-catenin signaling pathway. Toxicol. Appl. Pharmacol. 272(1), 180-190 (2013).

43. Lv J, Wang Z, Zhang L et al. Mangiferin induces apoptosis and cell cycle arrest in MCF-7 Cells Both in vitro and in vivo. J. Anim. Vet. Adv. 12(3), 352-359 (2013).

44. Zasada I, Zajac D, Pozdzik M, Pokorski M. Influence of Mangiferin on Lipid Peroxidation Presented at: International Conference 'Advances in Pneumology'. Bonn, 17-18 June (2011).

45. Kavitha M, Manivasagam T, Essa MM et al. Mangiferin antagonizes rotenone: induced apoptosis through attenuating mitochondrial dysfunction and oxidative stress in SK-N-SH neuroblastoma cells. Neurochem. Res. 39(4), 668676 (2014).

46. Gupta SK: US 20040241114 A1 (2004).

47. Gupta SK: US 20040156873 A1 (2004).

48. Peter DW, Stanek JD, Orozco CL, Gupta SK: US 8410079 B2 (2013).

49. Gupta SK, Walker L: US8227426 B2 (2012).

50. Park D-S, Yoo MC, Choi D-Y et al: WO 2009104913 A3 (2009).

51. Wang CC, Chen LG, Chang TL, Hsieh CT: US20110160152 A1 (2011).

52. Truog P, Buschmann HH: EP2698156 A1 (2014). 
53. Halbrook JW, Kesicki EA, Burgess LE, Schlachter ST, Eary CT, Schiro JG: WO 2004085418 A3 (2005).

54. Siegelin MD, Altieri DC: US 20110268722 A1 (2011).

55. Gerk PM, Barr WH, Ritter JK: WO 2013049365 A3 (2013).

56. Huang AL, Wu G: US 8716353 B1 (2014).

57. Khwaja TA, Friedman EP: US 6113907 A (2000).

58. $\quad$ Leonard J, Goldman S, O'hara Jr R: US 8012475 (2011).

59. Omoigui O: US 20060078532 A1 (2006).

60. Huang AL, Wu G: US 8722040 (2014).

61. Huang AL, Wu G: (2013).

62. Gupta SK: US 7615546 B2 (2009).

63. Adam J, Dasse O, Parrott JA, Putman D: WO 2008100977 A3 (2008).

64. Huang AL, Wu G: US 8822544 B2 (2014).

65. Kim DH, Han MJ: WO 2014175543 A1 (2014).

66. Talamond P, Mondolot L, Gargadennec A et al: WO/2009/125017 A3 (2009).

67. Ueda F, Kakinuma C, Serizawa Y: WO/2010/035675 A1 (2010).

68. Winter RW, Riscoe MK, Hinrichs DJ: US 6613797 (2003).

69. Deshpande J, Ghanam K, Ewart S, Juturu V: US 20150141355 A1 (2015).

70. Gupta SK: US 20120189567 (2012).

71. Krishnan GG: US 8163312 (2012).

72. Krishnan V: US 20080207774 A1 (2008).

73. Auriol D, Nalin R, Robe P, Lefevre F: US 20140088030 A1 (2014).

74. Matsuda H, Nishida S: JP2009023935 A (2009).

75. Krishnan V: US 20080233062 (2008).

76. Gupta SK, Walker L: US 8212076 (2012).

77. Hoffmann E, Horres R, Faust V, Schreiber H, Von Holst A, Hoffmann M: US 20110160698 A1 (2011).

78. Ghosal S: WO/2006/078424 A2 (2006).

79. Park D-s, Yoo MC, Choi D-y et al: US 20110003018 A1 (2011).

80. Krishnan GG: US 20110236488 A1 (2011).

81. Huang AL, Wu G: US 8716352 (2014).

82. Thomas R: WO/2013/138871 A1 (2013).

83. Deshpande J, Ghanam K, Ewart S, Juturu V: WO/2015/075549 (2015).

84. Matute Almau C, Gomez MVS, Esparza RC et al: US 20090131339 A1 (2009).

85. Chambers TJ, Fuller K, Jagger CJ, Lean JM: WO/2004/093995 A2 (2004).

86. Khwaja TA, Friedman EP: WO/1997/039355 A1 (1997).

87. Vyas A, Syeda K, Ahmad A, Padhye S, Sarkar FH. Perspectives on medicinal properties of mangiferin. Mini Rev. Med. Chem. 12(5), 412-425 (2012).

88. Acosta J, Sevilla I, Salomón S, Nuevas L, Romero A, Amaro D. Determination of mangiferin solubility in solvents used in the biopharmaceutical industry. JPPRes. 4(2), 49-53 (2016).

89. Li H, Wang Q, Ding Y, Bao C , Li W. Mangiferin ameliorates Porphyromonas gingivalis induced experimental periodontitis by inhibiting phosphorylation of nuclear factor-kB and Janus kinase 1-signal transducer and activator of transcription signaling pathways. J. Periodont. Res. 1, 1-7 (2016). 
